\title{
Encuadres visuales en las fotografías de prensa del proceso de paz en Colombia*
}

\author{
Visual Framing in the Press Pictures of the Colombian Peace Process \\ Enquadramentos visuais em fotografias de imprensa sobre o processo de paz na Colômbia
}

\author{
Anna-Lena Dießelmann ${ }^{\text {a }}$ \\ Comundo, Colombia \\ annalena.diesselmann@posteo.de
}

Andreas Hetzer

Comundo, Colombia

andreas.hetzer@posteo.de
DOI: https://doi.org/10.11144/Javeriana.uh88.evfp

Recibido: 15 Junio 2017

Aceptado: 31 Enero 2019

Publicado: 20 Diciembre 2019

\section{Resumen:}

La presente investigación retoma discusiones de la sociología visual en torno a métodos provenientes de la lingüística y la semiótica que empezaron a ser utilizados para el análisis de productos visuales en las prácticas sociales. Proponemos el análisis de encuadre aplicado a la representación visual del proceso de paz entre el Gobierno de Colombia y las FARC entre el 2012 y el 2016 . El corpus consiste en fotografías de prensa del periódico El Tiempo por su relevancia como actor en el proceso de encuadre. Ofrece una metodología innovadora para comprender modos de interpretación hegemónicos en cuanto a la conversión de un actor bélico a uno civil y su reincorporación a la sociedad imperante.

Palabras clave: framing, frame, encuadre visual, imagen, fotografía, prensa, proceso de paz, Colombia.

\begin{abstract}
:
This research resumes some discussions in Visual Sociology about methods taken from the Linguistics and the Semiotics that became increasingly useful in the analysis of visual products in the social practices. We propose a framing analysis applied to the visual representation of the peace process between the Colombian Government and the FARC between 2012 and 2016. The corpus consists in pictures from the newspaper El Tiempo, as it is a relevant actor in the framing process. This work provides an innovative methodology to understand the ways of hegemonic interpretation intended to convert a war actor into a civilian actor and his/ her consequent reincorporation in the society.
\end{abstract}

Keywords: framing, frame, visual framing, image, picture, press, peace process, Colombia.

\section{Resumo:}

A presente pesquisa retoma discussões da sociologia visual sobre métodos de linguística e semiótica que começaram a serem usados para a análise de produtos visuais nas práticas sociais. Propomos a análise de enquadramento aplicado à representação visual do processo de paz entre o governo da Colômbia e as Farc entre 2012 e 2016. O corpus consiste em fotografias de imprensa do jornal El Tiempo pela sua relevância como ator no processo de enquadramento. $\mathrm{O}$ texto oferece uma metodologia inovadora para entender modos de interpretação hegemónicos em quanto à conversão de um ator bélico em ator civil e sua reincorporação à sociedade imperante.

Palavras-chave: framing, enquadramento visual, imagem, representação fotográfica, imprensa, processo de paz, Colômbia.

Notas de autor

\footnotetext{
a Autora de correspondencia. Correo electrónico: annalena.diesselmann@posteo.de
} 

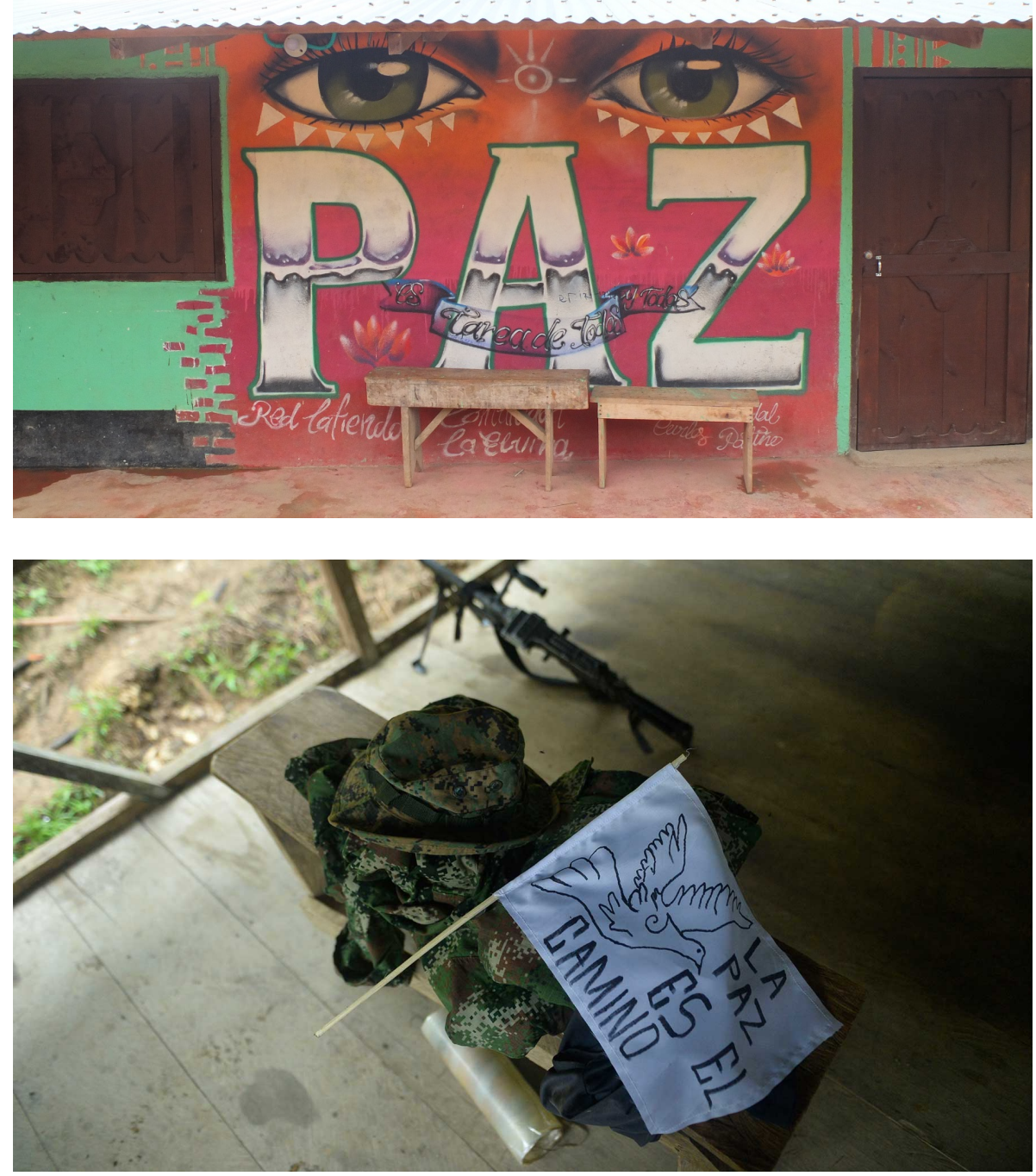

\section{Introducción}

El conflicto armado en Colombia duró más de cincuenta años y costó la vida a más de doscientas sesenta mil personas, desplazando a más de siete millones de habitantes. Los crímenes contra los derechos humanos, asesinatos selectivos y desplazamientos continúan formando parte de la cotidianidad en Colombia. De esta manera, los "diálogos de paz" entre las Fuerzas Armadas Revolucionarias de Colombia (FARC) y el Gobierno colombiano tuvieron gran acogida tanto a nivel nacional como internacional. Luego de que la mayor guerrilla del país realizara dos intentos fallidos con gobiernos anteriores, se considera la firma del tratado de paz a finales del 2016 como un acontecimiento extraordinario en la historia colombiana.

El interés científico de la coyuntura política parece quedar rezagado a pesar de la enorme atención mediática. El análisis presentado a continuación sobre el encuadre visual del proceso de paz pretende abordar esas lagunas en la investigación. Queremos analizar cuáles son los horizontes del sentido y la interpretación que aparecen a lo largo de las negociaciones en uno de los diarios más importantes del país, El Tiempo, y la manera como se interpreta la transición de un actor armado e ilegal. Partimos de la base de que los medios desempeñan un papel especial para promover la comprensión y la reconciliación de una sociedad plagada por 
el conflicto, tematizando las causas de este y contribuyendo al descubrimiento de la verdad. Las instituciones mediáticas igualmente seleccionan, filtran y estructuran la información y presentan al público un punto de vista específico sobre la realidad:

Modality-specific message properties shape the guided selection of information during perception; during the decoding stage, the involved perceptual processes have characteristic implications for possible interactions between perceived information and the perceiver's semantic and relational knowledge [...]. (Geise y Baden, 2015, p. 47)

Por lo tanto, las selecciones mediáticas tienen repercusiones sobre la percepción e interpretación de los acontecimientos políticos. La teoría del framing es especialmente apropiada para identificar esos marcos coherentes de interpretación y encontrar de esta forma determinadas ofertas de interpretación. Así, es posible entender el posicionamiento del medio y las coaliciones político-mediáticas para la construcción de la hegemonía.

El siguiente análisis se interesa particularmente en el encuadre visual debido a que las imágenes generan una mayor atención y son procesadas más rápidamente por los lectores. A partir de la lectura crítica, presentamos un modelo para la identificación de los encuadres visuales (visual frames) como fenómeno multimodal que va más allá de métodos de análisis de contenido y tipologías de imágenes, y que toma en serio la intersemiosis entre los diferentes formatos comunicativos. No obstante, a pesar de la omnipresencia de imágenes en la realidad que nos rodea, la mayoría de los innumerables estudios sobre framing se basa demasiado en los textos (Rodriguez y Dimitrova, 2011): "Mainstream framing theory and research has relatively little to say about the 'special logic' [...] of visual communication, losing traction with the increasingly multimodal media reality [...]" (Geise y Baden, 2015, p. 47). Solo en los últimos años se ha intensificado el debate sobre el framing visual, lográndose importantes avances en cuanto a la teoría y la metodología. Sin embargo, dos deficiencias continúan siendo virulentas: por un lado, predomina la literatura inglesa y poco se tiene en cuenta a la comunidad científica germano e hispanoparlante (Müller, 2013). En América Latina, con pocas excepciones (Cabrera, 2008), aún no ha sido utilizada la teoría del framing visual y su aplicación a estudios empíricos. Por otro lado, los análisis precedentes sobre framing visual tratan en su mayoría sobre guerras, conflictos, crisis, terrorismo, catástrofes naturales y migración (Geise, Lobinger y Brantner, 2013; López del Ramo y Humanes, 2016). En doble sentido, pisamos con ello un territorio inexplorado para Colombia en cuanto a que nos dedicamos a fondo a un tema del "periodismo de la paz" (Galtung, 1999), aceptando ofertas de tres comunidades idiomáticas a fin de que esta discusión sea fructífera.

\section{La teoría del framing}

Existe un amplio consenso en la teoría del framing en cuanto a que los encuadres representan marcos de interpretación, patrones de pensamiento u horizontes de sentido a fin de seleccionar, organizar, valorar y asociar significativamente determinados eventos y datos para activar esquemas cognitivos en los receptores, estructurar la percepción, generar apoyo o proceder con determinadas opciones para su actuación (Scheufele, 2003; Entman, Matthes y Pellicano, 2009). De esta manera,

[...] to frame is to select some aspects of a perceived reality and make them more salient in a communicating text, in such a way as to promote a particular problem definition, causal interpretation, moral evaluation, and/or treatment recommendation for the item described. (Entman, 1993, p. 52)

Los periodistas presentan, por lo tanto, sus perspectivas específicas y fomentan ciertos juicios o análisis que limitan el repertorio de soluciones posibles de problemas y organizan el discurso según una posición selectiva (Gandy, 2001; Entman, 2007). El centro de atención se enfoca en la manera como los medios se vuelven activos en el discurso público y cómo interpretan los acontecimientos políticos de manera significativa. Así mismo, participan en el lanzamiento de patrones de pensamiento selectivo según su directriz editorial. Los 
marcos de los medios de comunicación se entienden por consiguiente como variables dependientes. No solo se determinan por la voluntad de un editor poderoso (Cottle y Rai, 2006, p. 164), sino que dependen tanto de múltiples factores de influencia, como de procesos de control y jerarquías dentro de la redacción, estatus subjetivos de propiedad y criterios económicos de rentabilidad (Gandy, 2001; Weischenberg, 2004; De Vreese, 2005). Entonces, los medios deben ser entendidos como actores estratégicos que participan en la lucha por el papel determinante en el proceso de paz colombiano: "Los encuadres también son herramientas o inclusive armas fundamentales que son utilizados en estas batallas de interpretación" (Donati, 2001, pp. 151-152). Luego de comprender lo anterior, la investigación de encuadres noticiosos se pregunta por las preferencias del discurso de la prensa y su lógica de presentación sobre la realidad social. La marcada tendencia informativa generalmente se considera manifiesta cuando se mantienen determinados puntos de vista de manera repetitiva y a lo largo de periodos más extensos (Entman, 2010).

En este contexto, el análisis de encuadres está en condiciones de conectarse con el análisis crítico del discurso (Donati, 2001) al hacer que la orientación y perspectiva política de los actores mediáticos sea transparente. Rein y Schon (1991, p. 267) califican este enfoque como "frame-critical policy analysis", porque se identifican las presuposiciones y opciones de acción consideradas por los medios evidentes y aparentemente naturales. Los actores mediáticos aprovechan su posición privilegiada en el discurso político-mediático a fin de ejercer influencia sobre el campo político y sus relaciones de fuerzas. Por consiguiente, a través de los medios se dejan elaborar posiciones políticas: "Content bias refers to consistently slanted framing of mediated communication that promotes the success of a specific interest, party or ideology in competitions to control government power" (Entman, 2010, p. 393). Con ello se tematiza la relación entre los encuadres de los medios de comunicación y el poder político que con frecuencia se descuida en la teoría del framing (Carragee y Roefs, 2004).

\section{La importancia de las imágenes en el proceso del framing}

Como ya se mencionó en la introducción, los estudios sobre el framing se concentran en su mayoría en encuadres textuales. Aunque la teoría del framing pertenece a una de las líneas de investigación más importantes en la ciencia de las comunicaciones y la investigación de las comunicaciones políticas, la multimodalidad de los contenidos mediáticos permanece oculta. Ya en 1991, Robert Entman advirtió sobre el significado de los diferentes sistemas de signos durante la constitución de los encuadres. Dentro de diferentes narraciones periodísticas "frames can be detected by probing for particular words and visual images that consistently appear in a narrative and convey thematically consonant meanings across media and time" (Entman, 1991, p. 7). No obstante, esta constatación fue ignorada durante largo tiempo. Esto es aún más sorprendente ya que con el invento de la fotografía una serie de teóricos aseveró que las fotografías llevan a que el observador otorgue una mayor credibilidad del representado a raíz de su aparente naturalidad y parecido con la realidad. ${ }^{1}$ La exactitud de los detalles en la fotografía facilitaría la comprensión de los acontecimientos diarios ya que las imágenes están cerca de la realidad a partir de una variedad de posibilidades de interpretación de determinados tipos de lectura. Las representaciones visuales serían entonces especialmente relevantes para la interpretación y el sentido conferido a la realidad reproducida (Ortega Olivares, 2009; Rodriguez y Dimitrova, 2011). Contrario a la secuencialidad y la calidad argumentativa de los textos, la presentación visual de informaciones tendría lugar en forma sincrónica y jerárquica: "La comunicación visual sigue una lógica propia, no argumentativamente racional, presentativa y holística. El principio de esta lógica es la asociación" (Müller y Geise, 2015, p. 37).

De las particularidades de la comunicación visual se puede concluir que "especialmente las imágenes pueden ser descifradas más rápidamente, recibidas casi automáticamente y elaboradas mediante un control cognitivo menor" (Geise y Baden, 2013, p. 151). Las reacciones emocionales y etapas mentales de 
procesamiento se inician más rápidamente con la percepción de las imágenes que con los elementos verbales. Esto facilita también un reconocimiento más directo de los elementos visuales para la elaboración de analogías y el vínculo de la representación visual con los elementos de conocimientos ya existentes.

Debido a la reserva de las imágenes, el público se inclinaría más bien a aceptar los encuadres visuales (Rodriguez y Dimitrova, 2011). Colectivamente, "esto debería tener un efecto implícito sobre la evaluación de la precisión y la peculiaridad de las informaciones comunicadas visualmente" (Geise y Baden, 2013, p. 155). Esto se denomina comúnmente en la literatura como "picture superiority effect" y ha sido documentado en diversos estudios (Wanta, 1988; Coleman y Banning, 2006).

Los ensayos de definición de los encuadres visuales poco se diferencian, tras lo afirmado hasta ahora, de la definición de encuadres textuales:

Análogamente, un encuadre visual se constituye en una unidad seleccionada y semántica, presentada simultáneamente, de diferentes elementos de información visual significativos, que pone a disposición al receptor el modelo visual de interpretación con el cual se puede clasificar y elaborar eficientemente las informaciones. (Müller y Geise, 2015, p. 265)

Esta atribución de significado y elaboración de los modelos de interpretación claramente tiene lugar de manera contextualmente específica y se ha incrustado dentro del discurso correspondiente. No obstante, es motivo de controversia si los encuadres visuales surgen a partir de elementos visuales o más bien de una serie de imágenes que demuestran determinadas relaciones de similitud y que aparecen repetidamente (Herbers y Volpers, 2013). Nosotros abogamos aquí por la última opción puesto que los encuadres visuales surgen tan solo por la relación mutua de los diferentes elementos figurativos dentro de la composición visual total de una imagen, siempre y cuando composiciones similares se acumulen y aparezcan de manera continua. Solo entonces se puede hablar de una "central organizing idea" con sentido (Gamson y Modigliani, 1987, p. 143).

\section{Una propuesta para la identificación de encuadres visuales}

Mientras que en las definiciones existe un amplio consenso sobre framing y encuadres, no se puede decir lo mismo a la luz de la identificación empírica de los encuadres visuales. El material contempla un sinnúmero de procesos diferentes para la generación de encuadres visuales (Rodriguez y Dimitrova, 2011). En algunos estudios se observa igualmente cómo las categorías de contenido del análisis de imagen resultan en encuadres. A continuación, formulamos algunas premisas teóricas para la aclaración de estas incertidumbres a fin de descartar determinados procesos de generación de encuadres visuales. A partir de ahí planteamos una propuesta metodológica en cuatro pasos, la cual —en nuestra opinión - se deja utilizar con cualquier material gráfico. Esta metodología se inspira, por un lado, en el planteamiento iconográfico-iconológico de Grittmann (2013) y, por otro, en el "four-tiered framework for frame identification and analysis" de Rodriguez y Dimitrova (2011, p. 61). Pese a que en la literatura se suele distinguir claramente entre teoría y empirismo, consideramos que las siguientes declaraciones permiten lograr una mejor comprensión de la manera como identificamos los encuadres visuales a partir del material.

\section{Premisa 1. Encuadres como elementos para organizar el discurso}

Ya que, como se describió, los encuadres visuales se constituyen en componente visual de los discursos políticos lanzando y legitimando determinadas posiciones, estos pueden ser fructíferos para el análisis del discurso. Igualmente, debe enfatizarse que los encuadres no pueden ser equiparados con el discurso del proceso de paz en Colombia, debido a que el orden del discurso es sustancialmente más amplio y contiene acciones habituales y dispositivos materiales para la aclaración del equilibrio de poderes junto con las formas mediáticas de comunicación. Así mismo, el análisis del discurso pone a disposición herramientas desigualmente amplias, 
de manera que la visión restringida de la constitución de encuadres solo puede ser un instrumento que reduce la complejidad a fin de elaborar marcos interpretativos dentro del discurso del proceso de paz en Colombia (Olave Árias, 2011).

\section{Paso 1. Tendencias principales en la representación visual del proceso de paz}

Tomando como base la relación entre el discurso y el encuadre, se llevó a cabo un acercamiento al material a través de su interpretación a fin de obtener una impresión visual inicial. A partir de ahí resultan obvias las primeras conjeturas e hitos que fueron enriquecidos con el conocimiento de fondo del proceso de paz y sus eventos clave. En este paso se trata de elaborar las tendencias burdas del discurso e identificar especialmente los actores, los lugares, las situaciones y las acciones representadas. La aproximación del análisis del discurso se sirve de muestras iconográficas de análisis para la clasificación cronológica de los acontecimientos y de sus representaciones (Grittmann, 2013).

\section{Premisa 2. La identificación de encuadres visuales temático-específicos a partir del material empírico}

En la literatura encontramos una serie de estudios que establece los llamados encuadres genéricos (De Vreese, 2005). A raíz de la definición a priori y rígida de los encuadres transtemáticos y de la falta de sensibilidad frente al contenido temático específico dentro del proceso de paz en Colombia, consideramos que ese acceso deductivo es problemático. Por ello, abogamos por un método inductivo de encuadres visuales temático-específicos a partir del material empírico, ya que "con los datos se debe determinar si un horizonte consistentemente razonable de un actor puede ser codificado o identificado o no" (Matthes, 2007, p. 139). Los encuadres visuales solo son generados e interpretados durante el análisis a fin de garantizar "la transparencia principal con respecto a la cifra y definición de contenido de los encuadres" (Dahinden, 2006, p. 206). Igualmente, nos apartamos de una diferenciación en "substantive and procedural frames" (Entman, 2004, p. 6) en los discursos políticos (p. ej. Grittmann, 2013), y de la idea de que tanto la interpretación causal como la recomendación de tratamiento para el problema descrito en ambos tipos de encuadres pueden desempeñar un papel y, en consecuencia, algunos actores o propuestas de solución pueden ser (des)legitimados. Esto significa que se pueden suministrar razonamientos a ambos niveles, especialmente cuando la imagen se observa en su contexto multimodal.

\section{Premisa 3. Encuadres visuales como fenómeno multimodal}

Como se desprende de otros estudios, las diferentes formas de comunicación interactúan dentro de las constelaciones multimodales de manera que "los componentes monomodales del mensaje no solo deben ser analizados paralelamente, sino especialmente en su interacción, a fin de lograr una amplia comprensión de los encuadres en los medios de comunicación" (Lobinger y Geise, 2013, p. 333). Es interesante anotar que esto solo se presenta en contadas ocasiones. A partir del conocimiento de que cada imagen no necesariamente es rica en detalles ni cada afirmación verbal forzosamente es racionalmente argumentativa, podemos concluir que los encuadres visuales no solo son efectivos en su contexto discursivo debido a sus intersemiosis de recursos semióticos verbales y visuales (Lobinger y Geise, 2013) y, por tanto, deben ser decodificados. Por consiguiente, es necesario tomar en consideración tanto el título de la imagen como el título del artículo, en su mayoría resaltado tipográficamente para cada imagen, ya que cumplen con "una función de puente en los textos mediáticos multimodales" al "conectar la imagen retratada con los elementos textuales de la noticia 
contextualizando con ello la imagen" (Mellese y Müller, 2012, p. 208). De esta manera, podemos enfrentarnos al reto de que las imágenes basadas en su potencial polisémico pueden ser asignadas a diferentes encuadres dependiendo de su contextualización: "Con respecto a los estudios de framing se concluye que el título de una imagen, es decir, de un titular, logra hacer más creíble un significado más específico de la imagen dentro del espectro de significados potencialmente posibles de una imagen" (Lobinger y Geise, 2013, p. 341). ${ }^{2}$

\section{Premisa 4. La deficiencia del análisis de contenido para identificar encuadres visuales}

La conformación de categorías y la codificación confiable de contenidos gráficos se constituye en una tarea complicada debido a la apertura de la identificación de las imágenes, ya que las categorías presentan baja profundidad de análisis y poco se prestan para registrar intersubjetivamente la complejidad de lo visual (Müller y Geise, 2015, pp. 201-202). La estructura de la superficie (por ejemplo, diseños característicos, objetos, relaciones) y la estructura interna de la imagen (por ejemplo, símbolos, estereotipos, tendencia gráfica) permiten ser formuladas con una fiabilidad intercódigos satisfactoria. No obstante, el análisis de contenidos alcanza unos límites claros durante la formulación de importantes características latentes e implícitas, es decir, en torno a su estructura visual profunda que, por definición, apenas constituye al encuadre visual (Herbers y Volpers, 2013, pp. 89-90). En resumen, los análisis de contenido son inadecuadamente concebibles para ser registrados:

Mientras la investigación no se haya puesto de acuerdo sobre un catálogo de criterios para la investigación de encuadres visuales en los medios de comunicación, será necesario elegir los elementos de análisis para cada investigación de manera individual y repetida. (Herbers y Volpers, 2013, p. 85)

En el aspecto metódico se recomienda, por lo tanto, tener en cuenta tanto la incrustación mediática de la imagen correspondiente como el contexto discursivo (Herbers y Volpers, 2013, p. 89).

\section{Premisa 5. La tipología de imágenes como recurso para identificar encuadres visuales}

La estrechez del estudio de contenido para captar el encuadre visual trae instrumentos de análisis al primer plano que incluyen métodos visuales de presentación repetidos. La identificación y el registro de tipos de imágenes parecen ser especialmente adecuados para este fin debido a que clasifican las diferentes imágenes agrupándolas en tipos de imagen a un nivel más alto (Grittmann, 2007): "El interés del análisis se centra entonces menos en elementos gráficos individuales y más en la estructura total de la imagen localizada en el tipo de fotografía y su enunciado general' (Müller y Geise, 2015, p. 213). El enfoque se basa entonces en la elaboración de modelos de enunciados recurrentes dentro de la comunicación periodística visual, a partir de los cuales es posible identificar los encuadres visuales individuales. Así mismo, debe prestarse atención al hecho de que el enunciado principal de una imagen en particular depende del discurso correspondiente, permitiendo diferentes interpretaciones (Herbers y Volpers, 2013). Contrario a la comprensión de encuadres textuales durante el transcurso de la codificación y agrupación de elementos individuales (Entman, 1993), se recomienda la siguiente secuencia inversa en los encuadres visuales: al comprender el enunciado total de la relación imagen-texto y con ello el encuadre visual específico del discurso, se pueden derivar posteriormente en detalle los elementos constitutivos del encuadre, que serán descritos detalladamente y podrán ser ilustrados con ejemplos emblemáticos del material gráfico. 


\section{Paso 2. La identificación de encuadres visuales mediante enunciados principales}

Todas las imágenes disponibles fueron agrupadas inicialmente según el motivo de la imagen y luego resumidas según tipo de imágenes dentro de un análisis iconográfico cualitativo (Grittmann y Ammann, 2011). Los principios de la teoría del Gestalt como cercanía, parecido, finalización, equilibrio y simetría nos ayudaron concretamente a recopilar los diferentes elementos de la imagen dentro de su relación coherente, reconocer características en común de la configuración de las imágenes y, finalmente, conformar agrupaciones (Rodriguez y Dimitrova, 2011). Según Richter (2011) y Gamson (1992), se parafrasearon adicionalmente los planteamientos centrales para cada artículo adicionando su título y el de la imagen, y anotándolos en pocas frases mediante un memorando. Por este motivo la imagen sola no se constituye en unidad de análisis, sino que también se incluye el artículo con elementos gráficos y de texto, de manera que solo se puede codificar un encuadre visual por artículo periodístico. Al llevar a cabo este paso, y en razón a los correspondientes pies de fotos, se evidenció la presencia de diferentes planteamientos centrales dentro de la misma imagen. Después, y siguiendo la misma regla gramatical, se redujeron los planteamientos centrales a lo esencial y solo entonces se resumieron y abstrajeron en el próximo nivel superior a fin de reunir los enunciados con un significado similar (Mayring, 2008). Finalmente, se agruparon imágenes similares en su modo de presentación con el mismo contenido informativo comprimiéndolas en encuadres visuales. ${ }^{3}$ Dentro de los encuadres visuales se identificaron elementos constitutivos en concordancia con la definición de Entman (1993), siempre y cuando estuviesen presentes. Según la comprensión de Rodriguez y Dimitrova (2011) sobre "visuals as denotativesyntactic systems (Who or what is being depicted here?)", se incluyeron los resultados del análisis de contenido a la densa descripción de los encuadres visuales.

\section{Paso 3. La importancia y la valencia del framing visual}

A fin de determinar la importancia de cada encuadre visual en su proporción, se determinó, por un lado, la frecuencia de su aparición y, por otro lado, su emplazamiento dentro del producto mediático. En línea con el significado de "visuals as stylistic-semiotic systems" (Rodriguez y Dimitrova, 2011, p. 48) operacionalizamos la valencia visual de las fotografías sobre elementos gráficos de composición, es decir, los medios estilísticossemióticos del idioma gráfico: "This level also takes into account the stylistic conventions and the technical transformations involved in representation” (Rodriguez y Dimitrova, 2011, p. 54). De esta manera, se pueden cargar emocionalmente los objetos y las personas representadas edificando una relación social y simbólica entre la imagen y el espectador (Fahmy, 2004; Geise, Lobinger y Brantner, 2013).

\section{Paso 4. Significados simbólicos e ideológicos de los encuadres visuales}

En este punto reunimos los dos últimos niveles de análisis de Rodriguez y Dimitrova (2011) e incluimos el nivel iconológico de significado (Grittmann, 2013). Ya que el simbolismo de las imágenes está altamente convencionalizado y su comprensión depende del repertorio interpretativo cultural, se pueden cargar los elementos visuales dentro de su contexto discursivo de forma ideológica, marcando una conexión directa con los conceptos de valores implícitos de los periodistas y los medios: "The special qualities of visuals their iconicity, their indexicality, and especially their syntactic implicitness- makes them very effective tools for framing and articulating ideological messages" (Messarias y Abraham, 2001, p. 220). La dirección de impacto de la crítica ideológica requiere de las formas de representación reinantes, de los actores dominantes y de los patrones de pensamiento hegemónicos durante el transcurso de las negociaciones de paz dentro de un contexto más amplio de interpretación. Ya que esto, por así decirlo, representa la síntesis de los análisis empíricos, regresaremos a ello en las conclusiones. 
Conforme a lo dicho en los apartados anteriores, nuestra perspectiva teórica enfatiza que se puede comprender encuadres visuales como resultado de un proceso de selección de ciertos aspectos de la realidad haciéndolos más sobresalientes. De esta manera, los periodistas limitan los posibles modos de lectura para dar cierto sentido al proceso de negociación entre las FARC y el Gobierno. Por consiguiente, participan activamente en la batalla por la interpretación de los hechos y crean comunidades de interpretación para la construcción de hegemonía política-mediática.

Según este orden de ideas, la identificación de encuadres visuales dentro de una narración discursiva debe tener en cuenta su multimodalidad y partir del método inductivo de encuadres visuales temático-específicos para no perder de vista el contexto concreto del proceso de paz en Colombia. Nuestro interés del análisis de encuadres visuales se centra en la estructura total de la imagen localizada en el tipo de fotografía, de modo que agrupamos y clasificamos todas las imágenes disponibles según sus características en común. Esto nos permite resumir el enunciado general de cada encuadre visual constituido por sus elementos individuales para identificar los encuadres visuales que priman en la organización del discurso. Finalmente, el resultado del análisis iconográfico cualitativo nos posibilita abordar el nivel iconológico de significado, es decir, el sesgo político-ideológico del repertorio interpretativo presentado.

\section{El conflicto armado y el proceso de paz en la literatura}

Existen numerosas investigaciones analíticas del discurso sobre el conflicto colombiano que demuestran que los periodistas adaptan los patrones de pensamiento a los actores armados del conflicto, "que justifican el conflicto armado colombiano en términos de medios a fines" (Olave Árias, 2011, p. 533). Los medios no se comportan en absoluto de forma neutral, sino que disponen de recursos lingüísticos y de la incorporación de un argot en el conflicto (Serrano, 2015; Dießelmann y Hetzer, 2018). Así, una comparación de la representación de las acciones de la guerrilla y los paramilitares en la prensa arroja como resultado que las de la primera son nombradas explícitamente, identificando a los responsables, mientras que los ataques paramilitares son descritos de manera no diferencial y se duda de la autoría con un vocabulario denotativo, es decir, este queda confuso (García-Marrugo, 2013). En general se puede decir que los medios públicos y privados siguen una lógica instrumental al reportar sobre el conflicto, adoptando la versión del Gobierno y los militares sobre las causas y consecuencias de este (López de la Roche, 2015). El presidente Santos pudo inclusive mover la percepción de su personaje y de la realidad colombiana hacia una "construcción de una nueva Colombia” (Duarte García, 2012, p. 683), porque —en comparación con su antecesorpractica cuidadosamente una nueva política de imagen y sabe utilizar hábilmente la diplomacia de la paz (Duarte García, 2012; Bocchi, 2013; Dießelmann y Hetzer, 2015). Estos trabajos de análisis del discurso suministran importantes puntos de referencia para nuestro análisis de encuadres visuales, dejando, sin embargo, desatendida la multimodalidad del reportaje medial (con excepción de Olave Árias, 2013). En este sentido, el análisis aquí presentado se encuentra en territorio virgen ya que por primera vez toma en cuenta la representación visual de la totalidad de las negociaciones de paz.

\section{Objetivos e hipótesis del análisis empírico}

La meta del análisis de fotografías de prensa del proceso de paz entre las FARC y el Gobierno consiste en captar su dramaturgia discursiva y las ofertas de interpretación. Así mismo, no nos quedamos en un solo nivel descriptivo, sino que ponemos de relieve el posicionamiento y la orientación ideológica del periódico resultante del framing visual. A nivel de contenido, partimos de la base de las siguientes hipótesis que se derivan parcialmente de los trabajos preparatorios mencionados: 
H1: la dramaturgia discursiva del proceso de negociaciones que duró cuatro años entre las FARC y el Gobierno se desarrolla a manera de funcionamiento normal político del anuncio de los resultados de las negociaciones. Estos solo son interrumpidos por "perturbaciones" individuales (por ejemplo, conflicto militar, rechazo al primer acuerdo durante el referendo popular). El proceso de paz es presentado conjuntamente de forma positiva.

$\mathrm{H} 2$ : la transición del uribismo al santismo no solo expresa una nueva orientación política, sino que tiene repercusiones a nivel discursivo. El alegato del presidente Santos "de 'des-escalar', no solo las acciones militares, sino el lenguaje para designar al enemigo" (citado en López de la Roche, 2015) nos conduce a la hipótesis de que las FARC, a pesar de su estructura militar existente durante el proceso de paz, son representadas más bien como un actor político y como parte negociadora legítima. Nos unimos a la suposición de López de la Roche (2015): "Durante las conversaciones o procesos de paz, el enemigo tiende a verse como menos monstruoso, y se produce una cierta humanización del mismo". Por lo tanto, no se esperan muchas fotografías de las FARC en uniformes militares, en acciones de combate o en campos guerrilleros.

H3: a pesar del esperado cambio positivo de la representación de la guerrilla, no existe un encuadre equilibrado de los actores participantes en el proceso político. De la tradicional cercanía de los medios al Gobierno, deducimos que existe una parcialidad a favor de este. Por lo tanto, deberían aparecer más encuadres positivos que atribuyan al Gobierno la competencia de las acciones para la solución del conflicto.

\section{Metodología}

Como se describió de manera detallada, proponemos un diseño de métodos para el estudio científico que combina piezas de discurso, encuadre y análisis de contenido con los modos de comunicación multimodales. En razón a la investigación pragmática, nos hemos concentrado en la selección fotográfica del diario $E l$ Tiempo, ya que forma parte de los cuatro diarios con cobertura nacional y es editado en la capital. Después del diario sensacionalista Q'Hubo y el periódico gratuito ADN, es el de mayor lectura en el país. Se constituye especialmente en referente para las élites políticas y periodísticas.

El periodo de investigación se extiende durante el tiempo de las primeras conversaciones entre las FARC y el Gobierno en agosto del 2012 y la fijación de la fecha de la entrega final de armas por parte de las FARC en diciembre del 2016. Durante ese periodo definimos muestras estadísticas según eventos clave. En total, identificamos cronológicamente 50 eventos examinando el material gráfico de los ejemplares 10 días antes y 10 días después del evento. En caso de que el evento presentara una mayor duración, lo seguimos en la prensa hasta su finalización. Tomamos fotografías de las imágenes así obtenidas al igual que del artículo y toda la página del diario analizando los datos en MaxQDA. En 40 casos de la cronología de eventos definida por nosotros en El Tiempo se publicaron artículos con imágenes. La mayoría de los eventos (17) ocurrieron en el 2016, por lo que se publicó la mayor cantidad de artículos. El Tiempo igualmente le concedió mucha atención a los eventos antes del inicio de las negociaciones. Aunque la cobertura informativa solo comenzó en agosto del 2015, se publicaron artículos sobre cinco eventos. En el 2013 (3 eventos) y en el 2014 ( 5 eventos) las negociaciones solo tuvieron un bajo valor noticioso, y en el 2015 (10 eventos) aumenta nuevamente la cifra de artículos sobre las negociaciones de paz.

En la misma fecha se publicaron parcialmente varios artículos con diversas fotografías relacionadas con un evento. Estos también fueron tenidos en cuenta. La fotografía y su referente textual (título del artículo y pie de foto) conforman la unidad de análisis para la identificación del encuadre visual. Partiendo de la observación de Wanta (1988) en cuanto a que los lectores prestan más atención a fotografías de mayor tamaño, para el encuadre tuvimos en cuenta solamente las que tienen las medidas más grandes por artículo. ${ }^{4}$ Las fotografías de igual categoría incluidas proporcionalmente por artículo fueron analizadas individualmente en cuanto a contenido pero agrupadas durante el análisis del encuadre visual ya que se trataba de representaciones visuales 
parecidas para el mismo evento. En total, se obtuvo un cuerpo de 84 fotografías incluidas en 75 artículos diferentes. Por lo tanto, el cuerpo para el análisis del encuadre visual contiene 75 unidades de análisis.

Antepusimos un estudio estandarizado de contenido de las 84 fotografías seleccionadas al análisis de discurso y encuadre, cuyos resultados formaron parte de los diferentes pasos del análisis. Se desarrolló una ficha de codificación basada en los trabajos previos de otros autores (Muñiz, Igartua y Otero, 2006; López del Ramo y Humanes, 2016) con base en el planteamiento y las metas. Por un lado, se analizaron los elementos detonantes en el sentido de la descripción iconográfica de las fotografías; aquí se ubicó el "contexto físicoespacial en el que transcurren los acontecimientos mostrados en las fotografías" y el "contexto humano, es decir, aquellos que describen a las personas que aparecen en las imágenes” (López del Ramo y Humanes, 2016, p. 91) en el punto central. Además, se formularon trece variables: acontecimiento (según la preselección), fecha, autor de la imagen, actualidad, lugar, actividad representada, escenario (adentro/afuera), elementos y objetos físicos, tipo de actor (individual/colectivo), rol de actores principales, sexo, vestimenta y gestualidad. Nos interesamos además tanto por la puesta en escena como por las herramientas estilísticas a fin de poder evaluar la valencia de los encuadres visuales. Las siguientes variables fueron determinantes para ese fin: angulación de la cámara, plano, estatismo/dinamismo de la acción y posición corporal de los protagonistas.

El emplazamiento de las fotografías demuestra que El Tiempo otorga un alto significado a las negociaciones de paz. Así, 62 de las 84 fotografías investigadas por nosotros fueron publicadas en las páginas 1 a 3 -es decir, casi las tres cuartas partes de todos los casos-. Todas las fotografías en la parte interna del periódico están enlazadas con un adelanto multimodal o textual en la portada. 60 fotografías contienen imágenes actuales (más 10 del archivo y 14 sin datos). 14 fotos fueron obtenidas a través de agencias del Gobierno o de las fuerzas militares y 11 de particulares. La mayor parte de la autoría de las fotografías se debe a agencias (25) y fotógrafos reconocidos (26). Ninguna de las fotografías proviene de fuentes de las FARC.

\section{Resultados}

\section{Tendencias principales de la representación visual}

Inicialmente llaman la atención las coyunturas burdas: al inicio del periodo de investigación predominan las comparaciones de los negociadores tanto por parte de sus famosos representantes como por parte de las delegaciones, quienes generalmente figuran sentados en la mesa de negociaciones en La Habana. Mientras que esa mesa y el espacio que hay detrás aún no se encuentran claramente marcados, durante el transcurso de las negociaciones se observa cada vez una decoración más explícita: primero con una pancarta marcada "Diálogos de Paz. La Habana, Cuba", y más adelante con la bandera colombiana y la rama verde a manera de símbolo de la paz. El espacio adquiere cada vez más un aspecto de escenario a medida que se desarrolla la representación. Esa escenificación culmina con la firma del tratado de paz en Cartagena, donde se realiza la apertura con un oficio religioso como representación de la escena, los actores y sus actuaciones.

La representación visual se observa paso a paso con imágenes de un apretón de manos y de las alocuciones a la prensa o al público. Con marcada diferencia, el tipo de imagen del discurso político se observa con mayor frecuencia. El 74\% de las fotografías fue tomado en un salón interior. De esta manera, se subraya el hecho de que las negociaciones se llevaron a cabo a puerta cerrada sin la participación de la sociedad civil. El proceso de paz es señalado como negociación entre las élites. Esto responde también a la falta de fotografías del tipo “mirada tras bastidores". Prácticamente no existen fotografías (2) fuera de la escenificación política.

En lo que se refiere a la representación de los actores, debe anotarse inicialmente que se trata de un proceso netamente masculino. Solo en tres imágenes se observan mujeres en forma de individuo como tal, únicamente el 30\% de las fotos contiene mujeres como parte del público o de un grupo y más del $66 \%$ de las fotos carece de un personaje femenino. La representación de las partes negociadoras también se halla distribuida 
inequitativamente: el Gobierno o su delegación aparece en 50 fotografías y en 23 de ellas solo aparece este. Santos y De la Calle aparecen en 15 oportunidades cada uno como persona. Las FARC aparecen en 27 imágenes, solamente 4 de ellas individualmente como grupo. Los militares aparecen sorpresivamente en 13 fotografías y en 4 de ellas se observan en intervención al aire libre. La oposición política solo se muestra en 3 fotografías y la sociedad civil, en 11 .

Con respecto a la representación de los actores, se puede observar que los representantes de las FARC no aparecen uniformados en ninguna de las fotografías. Las pocas tomas individuales de la delegación muestran a las FARC presentando excusas y pidiendo perdón. Solo una fotografía capta a Timochenko con un gesto de victoria. Por el contrario, los representantes del Gobierno son presentados en poses y situaciones favorables, de ahí que De la Calle siempre luzca dinámico y exigente. En 7 fotografías se aprecia a Santos rodeado de su equipo o simpatizantes de la sociedad civil, motivo por el cual gana legitimidad como actor del proceso de paz. Ligado a ello, sus gestos en las fotos individuales tienen un carácter casi pastoral.

Durante el periodo de investigación cambia el vestuario de los actores: todos los representantes de las negociaciones visten exclusivamente de blanco entre el momento de la concertación para una pronta finalización de las negociaciones en La Habana el 29 de mayo del 2015 y la firma definitiva en Cartagena el 27 de septiembre del 2016. Aunque en las fotografías previas a ese periodo predominaba el vestuario claro, no sucedía así en su totalidad. En las fotografías de las negociaciones posteriores a la firma en Cartagena y el plebiscito ya no se reconoce un vestuario unitario. Esa observación también subraya el alto grado de escenificación de las últimas fases de la negociación.

Las interrupciones de esas líneas principales en la representación se deben principalmente a los inconvenientes presentados durante la negociación, que a su vez son atribuidos sin excepción a incumplimientos de las FARC. La primera "alteración" se registra a raíz del secuestro de un general el 16 de noviembre del 2014, la segunda, el 15 de abril del 2016 con motivo de un ataque de las FARC a una unidad militar en el Cauca, el cual dejó 11 muertos. Durante esas interrupciones diariamente se presentan fotografías de la intervención militar en lugar de las negociaciones.

\section{Encuadres visuales}

Identificamos siete encuadres (tabla 1) con respecto a la reducción fragmentaria de los enunciados principales de cada elemento multimodal, siempre y cuando aparezcan al menos en $5 \%$ de todos los artículos. No se tuvieron en cuenta aquellos elementos que no superaron este umbral mínimo, por consiguiente, no fueron clasificados en ningún encuadre por su repercusión insignificante en el discurso.

TABLA 1.

Encuadres, enunciados principales y elementos de los encuadres

\begin{tabular}{|c|c|c|c|c|c|}
\hline $\begin{array}{l}\text { Encuadre } \\
\text { visual }\end{array}$ & Enunciado principal & $\begin{array}{l}\text { Definición del } \\
\text { problema }\end{array}$ & Medidas & Responsabilidad & Competencia \\
\hline Confrontación & $\begin{array}{l}\text { El Gobierno y las FARC } \\
\text { quieren dialogar }\end{array}$ & $\begin{array}{l}\text { Diferencias entre las } \\
\text { partes negociadoras }\end{array}$ & Diálogo & $\begin{array}{l}\text { Gobierno y las } \\
\text { FARC }\end{array}$ & $\begin{array}{l}\text { Gobierno } y \\
\text { las FARC }\end{array}$ \\
\hline Negociación & $\begin{array}{l}\text { El tratado se negocia en grupos } \\
\text { de trabajo }\end{array}$ & Lograr la unidad política & Diálogo de expertos & $\begin{array}{l}\text { Oposición } \\
\text { frontal }\end{array}$ & $\begin{array}{l}\text { Todos los } \\
\text { participantes } \\
\text { politicos }\end{array}$ \\
\hline Éxito & $\begin{array}{l}\text { La solución políica pone fin a } \\
\text { la guerra }\end{array}$ & Conflicto militar & Democracia/acuerdo & FARC & Gobierno \\
\hline Participación & "Queremos ser escuchados" & Escasa participación & Inclusión de los críticos & $\begin{array}{l}\text { Gobierno } y \text { las } \\
\text { FARC }\end{array}$ & Gobierno \\
\hline Militar & $\begin{array}{l}\text { Los militares permiten el } \\
\text { diálogolla paz }\end{array}$ & $\begin{array}{l}\text { Violencia por parte de } \\
\text { las FARC }\end{array}$ & Intervención militar & FARC & Militares \\
\hline Crisis & $\begin{array}{l}\text { Las FARC son culpables de la } \\
\text { crisis en las negociaciones }\end{array}$ & $\begin{array}{l}\text { Violencia por parte de } \\
\text { las FARC }\end{array}$ & $\begin{array}{l}\text { Las FARC se } \\
\text { disculpan/pronuncian }\end{array}$ & FARC & Gobierno \\
\hline Legitimidad & $\begin{array}{l}\text { El proceso de paz tiene } \\
\text { legitimidad politica }\end{array}$ & $\begin{array}{l}\text { Crítica sobre las } \\
\text { negociaciones }\end{array}$ & $\begin{array}{l}\text { Para promocionar } \\
\text { aprobación }\end{array}$ & FARC & Gobierno \\
\hline
\end{tabular}

El enunciado principal del encuadre de confrontación (figura 1) es "el Gobierno y las FARC quieren dialogar", basándose en el problema de las diferencias entre las partes negociadoras. Como medida, se propone el diálogo entre el Gobierno y las FARC de tal manera que ambos cuentan con las competencias 
correspondientes. Las dos partes "marcan sus diferencias", "dan señales de esperanza”, "definen mecánica para el diálogo" y siempre aparecen frente a frente en las imágenes.

Como elementos recurrentes se observan la mesa de negociaciones decorada formalmente, la pancarta oficial y el salón oficial de negociaciones en La Habana. Este encuadre representa el acto simbólico del encuentro de dos partes en conflicto. Las fotografías frecuentemente están ubicadas sobre un eje central vertical y cada delegación está en su costado correspondiente. Los líderes de las negociaciones se encuentran sentados en el centro de la imagen y, por ende, espacialmente cercanos. Las fotografías hacen seguimiento a una simultánea tensión entre división y unión ya que, por un lado, se traza una clara línea entre las delegaciones y, por otro lado, se fabrica una cercanía. Los textos enmarcan esa confrontación con palabras clave como diferencia, arranque, primer paso, duro cara a cara.

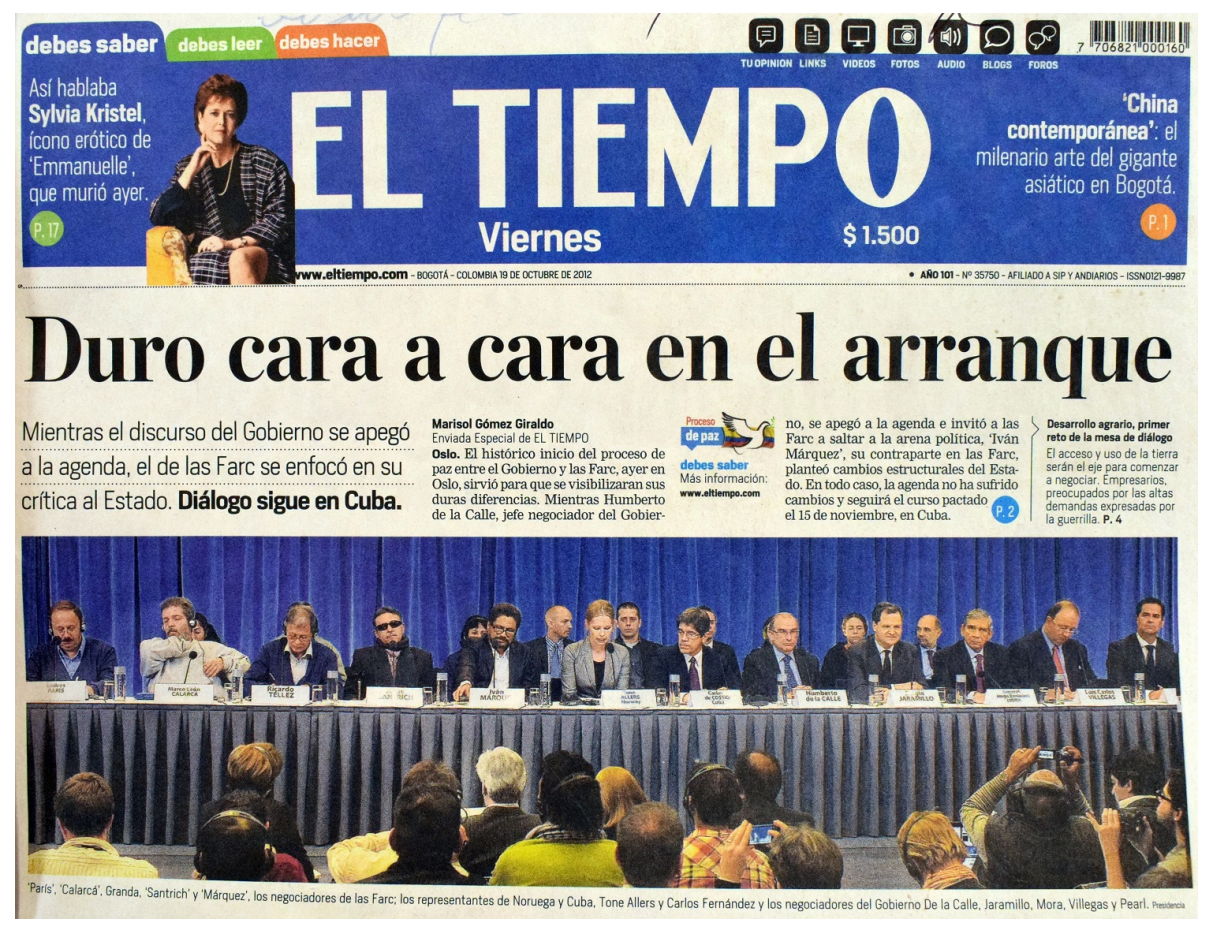

FIGURA 1.

Encuadre de confrontación

Fuente: El Tiempo (octubre 19, 2012).

El encuadre visual de negociación (figura 2) se puede resumir en el enunciado principal "el tratado se negocia en grupos de trabajo", donde las partes negociadoras consisten tanto de delegaciones como de expertos, y más adelante de comisiones parlamentarias y la oposición política. Se muestra la forma como se hace frente al problema de la unidad política a través del diálogo (de expertos). Sin embargo, contrario al primer encuadre visual, aquí no se muestra la situación escenificada de la mesa oficial de negociaciones, sino a los grupos de trabajo ubicados de algún modo detrás de la escenificación pública. El encuadre arroja una luz positiva sobre todas las partes políticas involucradas dentro del proceso porque la voluntad de todos los actores se ve representada por el intercambio entre opositores parcialmente políticos. Con ello se insinúa un proceso ordenado con entendimiento recíproco. El encuadre visual casi no está cargado simbólicamente. La agrupación de las personas alrededor de la mesa se realiza fundamentalmente en círculo o semicírculo, de tal manera que el observador recibe una impresión íntima del proceso de trabajo. Las fotografías se apoyan textualmente en términos como comisión, grupo especial, nuevo acuerdo, radicar reforma o pacto. Ese encuadre media entre el encuadre de confrontación y el de éxito ya que tiende un puente significativo entre las diferencias políticas y la unidad política. 


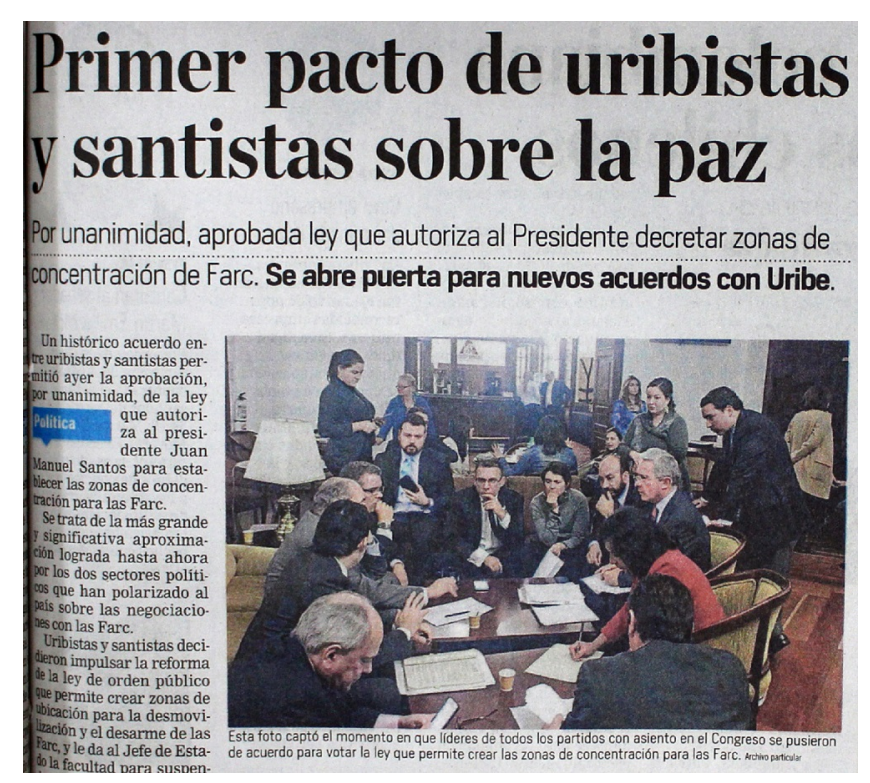

FIGURA 2.

Encuadre de negociación

Fuente: El Tiempo (marzo 10, 2016, p. 5).

El mensaje del encuadre de éxito (figura 3) es "la solución política pone fin a la guerra". El exitoso acuerdo por la vía democrática de esta manera da por terminado el conflicto militar. El encuadre representa el cierre, la conciliación exitosa, la solución triunfante al conflicto. Los valores de democracia y diálogo como conceptos inmunes a objeciones otorgan a los patrones de pensamiento su capacidad de penetración. Con ello el Gobierno, como representante legítimo de la población, se convierte en el actor competente y las FARC deben ponerse de acuerdo con él a manera de oposición política, es decir, subordinándose al proceder democrático. Durante las negociaciones, Márquez y De la Calle son los principales actores mientras que Timochenko y Santos lo son durante la firma. Junto a ambas delegaciones se observan también varios garantes internacionales del proceso, aunque es interesante observar que solo aparecen en función de espectadores o aplaudientes; le otorgan una mayor legitimidad a la negociación en las fotografías. El encuadre se ve gráficamente representado sobre todo en el gesto del apretón de manos, el cual implica la integración simbólica de las FARC al proceso democrático. La cercanía física y el aplauso presentan un contraste adicional a la representación visual en el encuadre de confrontación, el cual resaltaba la distancia. También llama la atención que el vestuario se integra cada vez más a la escenificación y que todos los participantes se visten de blanco. Los gestos y símbolos subrayan la exitosa transición hacia la paz. Las palabras clave son paz, democracia, fin de guerra, silencio de armas y firma. Queda claro que con este encuadre se refuerza la legitimidad del Gobierno y que las FARC son devueltas al funcionamiento legítimo y legal de la democracia, como el "hijo pródigo", interpretación que es reforzada por los símbolos religiosos y la escenificación. 


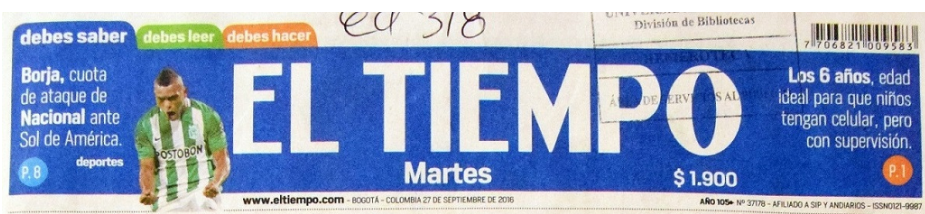

\section{'Bienvenidos a la democracia'}

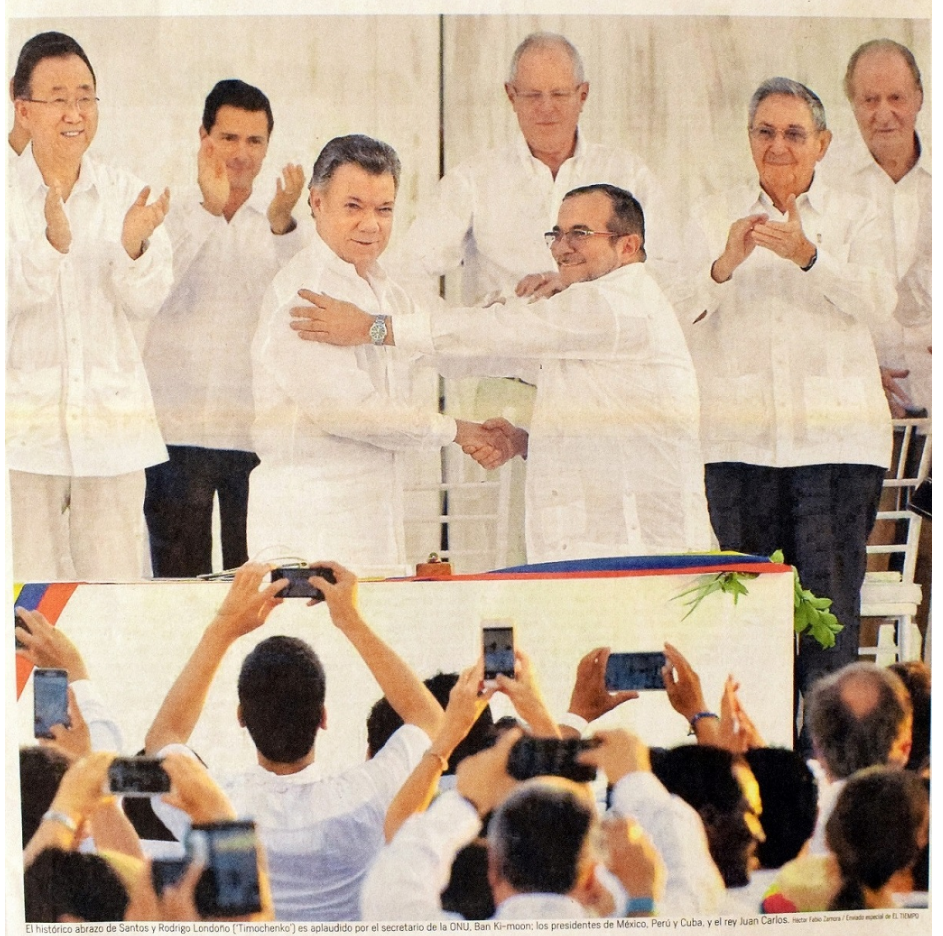

FIGURA 3.

Encuadre de éxito

Fuente: El Tiempo (septiembre 27, 2016).

El enunciado principal del encuadre visual de participación (figura 4) es "queremos ser escuchados". Denuncia la escasa participación durante las negociaciones de paz. Dicho enunciado no contiene una crítica sobre los anteriores encuadres visuales, sino que exige ser escuchado durante el diálogo. La crítica sobre una deficiente participación se dirige hacia el Gobierno y las FARC, sin embargo, como garante del Estado de derecho, el Gobierno dispone exclusivamente de los medios correspondientes. Los actores que desean ser escuchados son la población civil y la oposición política. Tratan de darle visibilidad a su posición a través de demostraciones con pancartas y banderolas, y, por lo tanto, dentro de ese encuadre se visualizan imágenes con un mayor nivel de acciones. Dentro del texto acompañando a las fotografías se encuentran términos como "debate", "diálogo", "discusión" y "escuchar". 


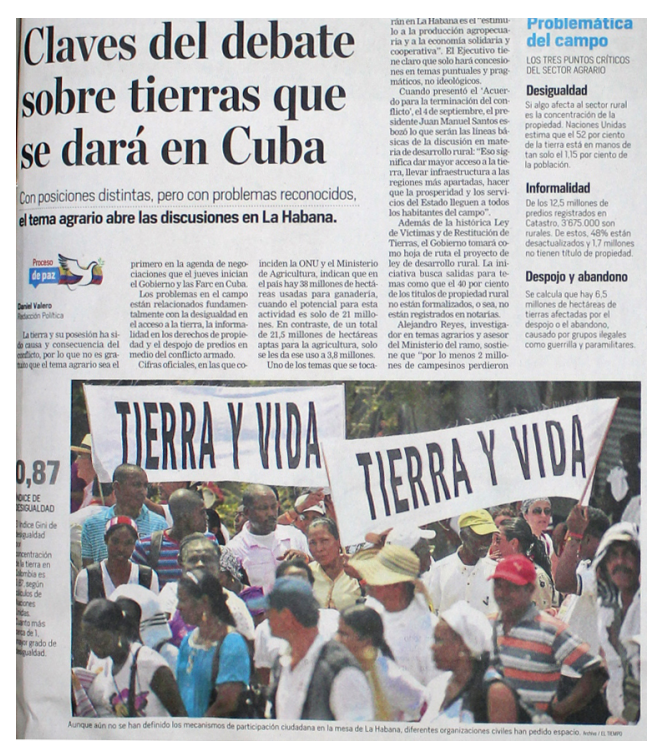

FIGURA 4.

Encuadre de participación

Fuente: El Tiempo (noviembre 11, 2012, p. 3).

Dentro del discurso de las conversaciones de paz de cierta forma se pueden señalar dos encuadres visuales como "encuadres de ruptura": el encuadre militar y el encuadre de crisis. Ambos reaccionan a obstáculos dentro de las negociaciones y sirven para poner en duda a las FARC y legitimar al Gobierno y las fuerzas militares como actores competentes. Las conversaciones de paz surgen así como una concesión a las FARC. Estas interferencias en las negociaciones siempre se desarrollan según el mismo patrón dentro de su dramaturgia. Las FARC son dibujadas como las responsables (encuadre de víctima), deben disculparse, a continuación son rehabilitadas como parte política de las negociaciones (encuadre de alocución o conferencia de prensa) y la interrupción concluye con la foto de un apretón de manos entre las delegaciones. Las fotografías subrayan un final de la dramatización de estos sucesos, normalizan los acontecimientos y legitiman con ello la continuación de las negociaciones. El encuadre militar aparece especialmente a raíz del secuestro del general Alzate por parte de las FARC en noviembre del 2014 y del atentado realizado por las FARC contra los militares en abril del 2015. El problema consiste en la violencia por parte de las FARC y las fuerzas militares se constituyen en el actor que puede resolver militarmente el conflicto. El encuadre visual contiene una confrontación directa entre las FARC y los militares, en la que las fuerzas militares son presentadas como actores más racionales, con una actuación más sensata y legítimamente políticos, mientras que las FARC atacan y secuestran, es decir, cometen crímenes. En las fotografías solo se observa a las fuerzas militares en acción, mientras que las FARC son señaladas a través de los elementos textuales (figura 5). Adicionalmente, las armas y los uniformes tienen un efecto casi contradictorio frente al vestuario blanco de las delegaciones negociadoras en los restantes encuadres. El contexto textual también subraya el importante papel que desempeñan las fuerzas militares: reacción, liberación, operación de las fuerzas militares se enfrenta a las FARC y a términos como masacre y conflicto armado. 


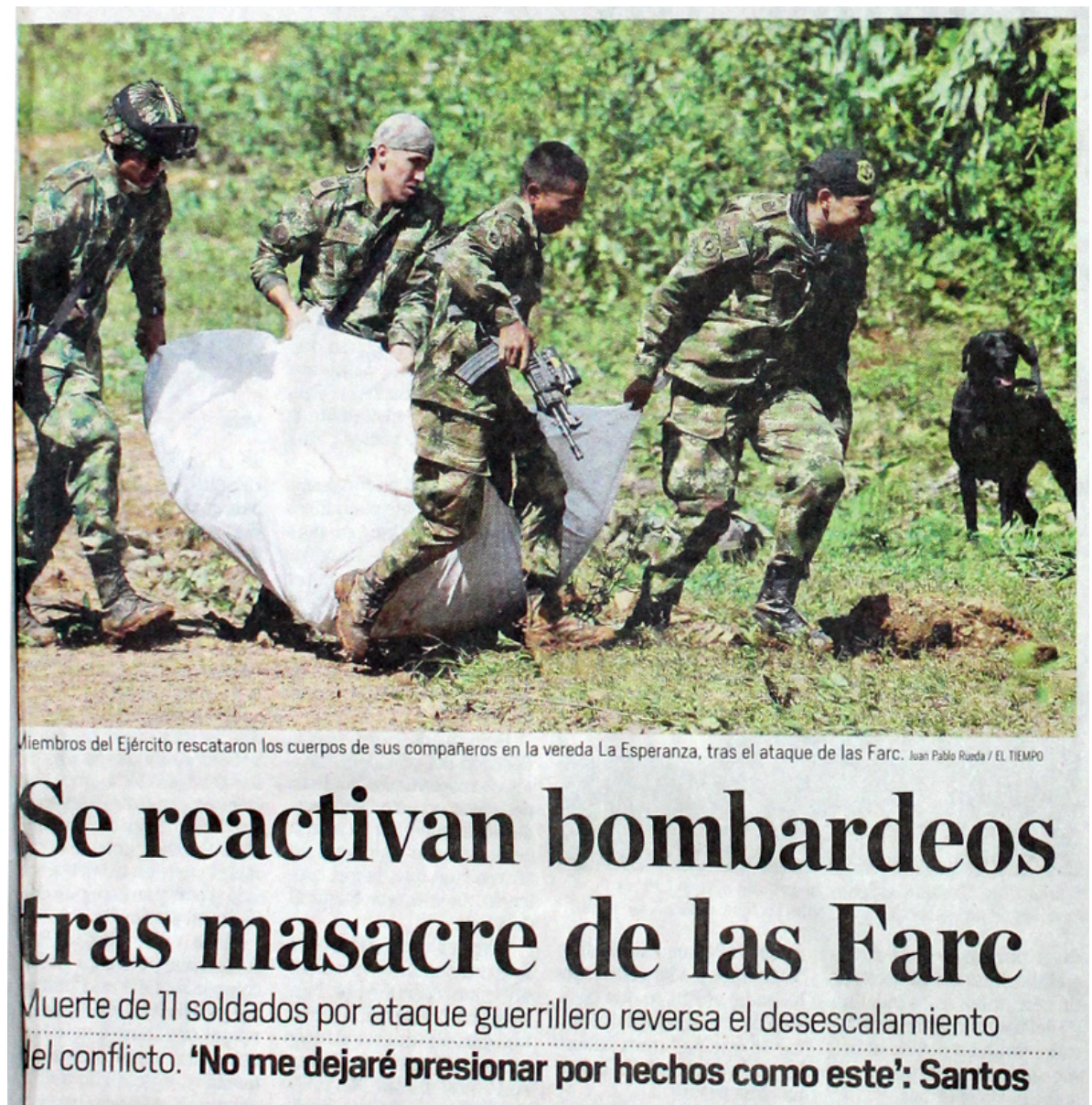

FIGURA 5.

Encuadre militar

Fuente: El Tiempo (abril 16, 2015).

El encuadre visual de crisis insinúa también la responsabilidad de los problemas durante las negociaciones con las FARC, las cuales están obligadas a tomar las medidas, disculparse, reconocer su culpa y pronunciarse. La habilidad para resolver estas crisis recae en el Gobierno puesto que otorga concesiones a las FARC y pone las condiciones reales bajo las cuales se puede continuar con la negociación. En este encuadre se observa la desconfianza frente a las FARC y sus "verdaderas intenciones". Solo en este contexto se publican fotografías únicamente de las FARC, precisamente porque tienen que disculparse con las víctimas o prometer frente a la prensa no continuar utilizando la violencia. Las FARC solo aparecen como un grupo y únicamente en situaciones de crisis, lucen derrotadas a través de sus gestos y luchan por su credibilidad. Dentro de los textos dominan términos como crisis, condiciones, dolor y no repetición. Con ello reiteradamente se ejerce presión mediática sobre el grupo negociador de las FARC y sobre su voluntad para lograr la paz. Dentro del contexto del titular de la figura 6 , se pone particularmente de manifiesto que las FARC representan más bien a los perdedores, a una fuerza más débil que se aparta del público. Aunque aquí se observa a las FARC durante una alocución, el título las coloca en una posición pasiva. El pie de foto también da a entender que las FARC anuncian un cese en las negociaciones, es decir que son responsables de las dificultades del proceso. 


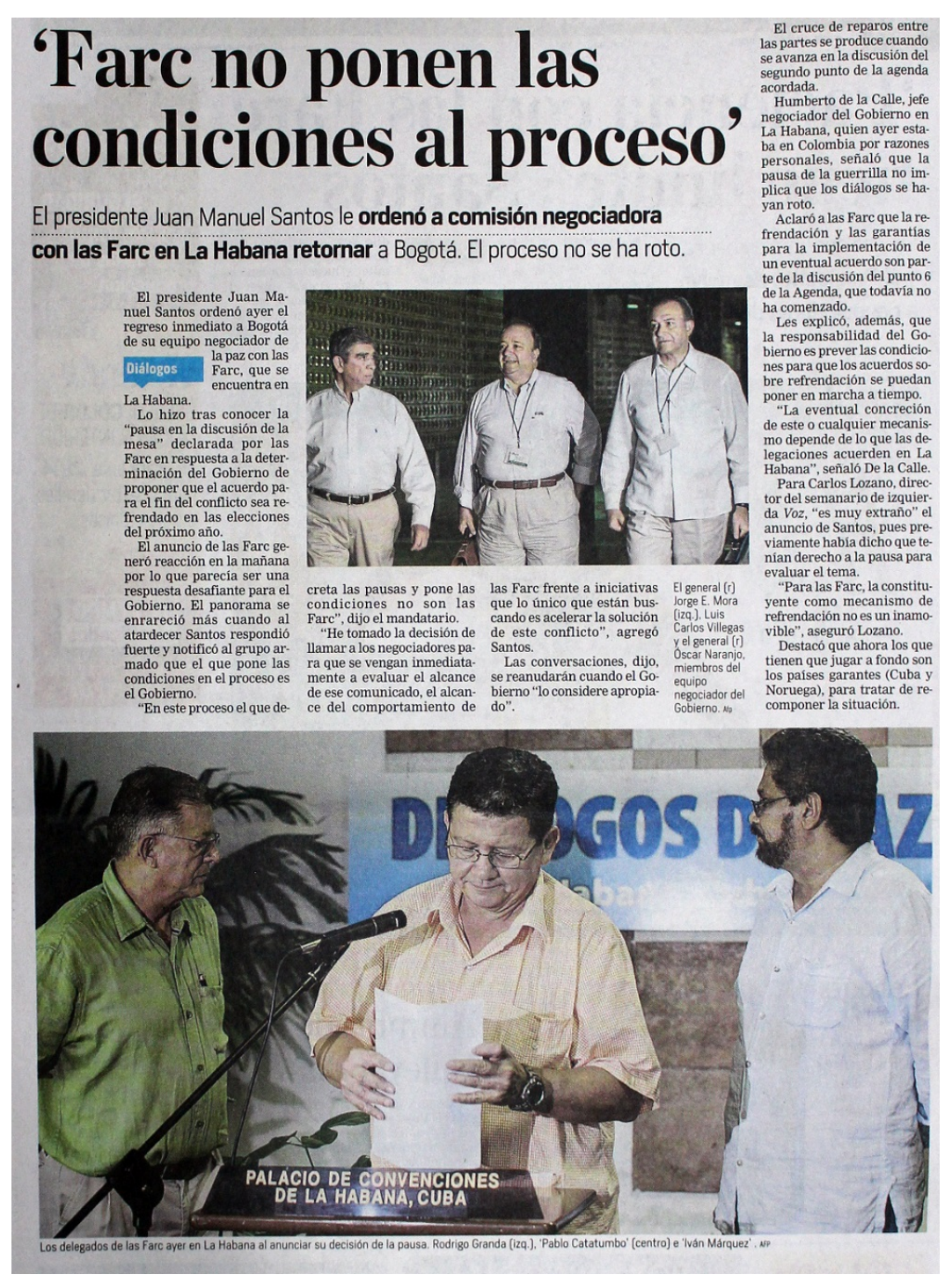

FIGURA 6.

Encuadre de crisis

Fuente: El Tiempo, 24 de agosto del 2013, página 2

El encuadre de la legitimidad (figura 7) se enfrenta de manera más directa al de la crisis. Los elementos visuales como los gestos, los escenarios y los lemas producen una imagen opuesta. El enunciado principal de legitimar el proceso de paz se constituye en una respuesta a la crítica sobre los diálogos de La Habana. Pretende convencer a la población sobre la legitimidad democrática y la veracidad de la negociación. Por ello, atribuye las habilidades para la solución del conflicto al Gobierno en representación del pueblo. Las FARC se constituyen simultáneamente en causantes del problema y parte de la estrategia de solución. Los principales actores son el presidente Santos como persona particular o rodeado de sus partidarios, y el negociador De la Calle como persona particular o con la delegación del Gobierno. Las fotografías de la delegación negociadora del Gobierno en La Habana, en las que De la Calle aparece en el centro del cuadro, se constituyen en lo más combativo y proactivo, lo cual se aprecia en el encuadre visual con aquellas imágenes en las que se muestra actividad y movimiento. Junto con los titulares queda claro que el Gobierno se enfrenta a desafíos buscando la aprobación de los críticos. La interacción entre imagen y texto luce atractiva y justificable al mismo tiempo ya que se aborda al lector y se le informa sobre las condiciones del Gobierno en cuanto a las negociaciones. 


\section{'Aquí no se ha pactado nada en contra del país': presidente Santos}

El mandatario envió un mensaje de tranquilidad a la tropa. También reiteró que el 23 de marzo se firmará el fin del conflicto. Llamó a la unidad.

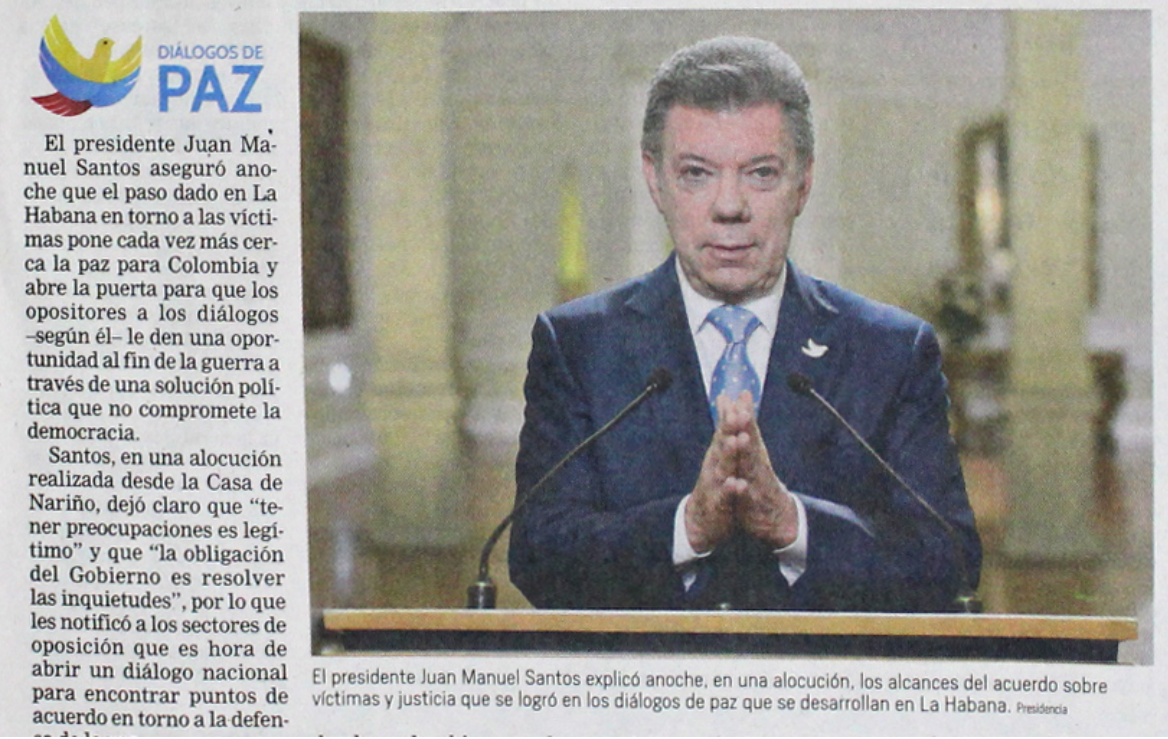

FIGURA 7.

Encuadre de legitimidad

Fuente: El Tiempo (diciembre 16, 2015, p.4).

\section{La importancia y la valencia de los diferentes encuadres visuales en el discurso}

De los 75 artículos, solo 5 fotografías no pudieron ser clasificadas en ningún encuadre debido a su singular mensaje central. Durante la distribución de los encuadres llama la atención que existe un equilibrio relativamente temático. El encuadre de confrontación y negociación, que favorece el diálogo como medida adjudicando a todos los actores participantes la responsabilidad del proceso de paz como vía para la unidad política, figura en el $20 \%$ de los artículos. El encuadre de éxito, que honra tanto los logros como el final del acuerdo con la firma, se presenta igualmente en el 20\% de los casos. Es interesante anotar que los encuadres de éxito diametralmente opuestos (a saber, militar y crisis) que contienen una clara atribución de culpa y arbitrio negativo de las FARC se presentan con frecuencia, endosando la garantía de la paz a las fuerzas militares. El encuadre de legitimidad permite ser registrado con mayor frecuencia al poner en escena a los representantes del Gobierno como responsables competentes. Las voces de la oposición o los actores de la sociedad civil que exigen una participación más fuerte cuentan con una representación marginal. Por consiguiente, cable concluir que predominan los modos de interpretación crítica hacia la FARC a pesar del reconocimiento de los éxitos de las negociaciones a través de una representación gráfica del Gobierno y las FARC. De esta manera se confirma la superioridad cuantitativa de la aparición de actores del Gobierno en las fotografías, con lo cual 
se sugiere a los lectores que el Gobierno es proactivo y competente para poder llevar a feliz término el proceso de paz.

TABLA 2.

Frecuencia de los encuadres en el transcurso del tiempo

\begin{tabular}{lrl}
\hline Encuadre & Frecuencia & $\begin{array}{l}\text { Presencia en el } \\
\text { transcurso del tiempo }\end{array}$ \\
\hline Confrontación & $12 \%$ & $2012-2015$ \\
\hline Negociación & $8 \%$ & $2014-2016$ \\
\hline Éxito & $20 \%$ & $2012-2016$ \\
\hline Participación & $5 \%$ & 2012 y 2016 \\
\hline Militar & $12 \%$ & $2014-2016$ \\
\hline Crisis & $8 \%$ & $2013-2016$ \\
\hline Legitimidad & $28 \%$ & $2012-2016$ \\
\hline $\begin{array}{l}\text { No se clasifica en } \\
\text { ningún encuadre }\end{array}$ & $7 \%$ & \\
\hline
\end{tabular}

Fuente: elaboración propia

Esta conclusión queda confirmada cuando el editor del periódico arrastra hacia la portada la publicación de fotografías de gran formato a manera de punto de referencia para la priorización de determinados patrones de pensamiento (Rodriguez y Dimitrova, 2011, p. 54), lo que en total sucedió en 14 ocasiones. El encuadre militar alcanzó la portada en 4 ocasiones y el encuadre de éxito, en 6. La hegemonía visual de ambos encuadres señala una vez más a las FARC como actor ambivalente capaz, por un lado, de llegar a acuerdos, pero cometiendo por otro lado masacres y atrocidades. El problema del conflicto militar como elemento clave del encuadre tiene por ello mucho significado para El Tiempo.

El presidente Santos, quien sistemáticamente recibe connotaciones positivas, es citado directa o indirectamente en la portada dentro del encuadre de participación y legitimidad: "Tras triunfo del 'No', Santos llama a diálogo político por la paz" (3 de octubre del 2015) y "gana el Nobel por insistir en la paz" (8 de octubre del 2016). Continúa mostrándose dispuesto al diálogo y es premiado en el exterior por su apuesta persistente por la paz incluso después de la oposición de la población. Por antonomasia aparece como figura de integración.

La valencia del correspondiente encuadre visual puede ser derivada de los medios formales y estilísticos. En todos los encuadres predomina el ángulo frontal. En el $87 \%$ de las fotografías se ha representado la escena captada a nivel de los ojos, lo que da una impresión formal y neutra. Solo el $5 \%$ de las fotografías fue tomado desde el ángulo contrapicado, de lo cual se puede deducir que esto sirve para distanciar al actor. Tan solo se captaron 4 fotografías desde el ángulo picado a fin de poder retratar a una mayor cantidad de personas.

El plano utilizado dio las claves para la construcción de cercanía y distancia, por lo tanto es interesante observar que solo el $2 \%$ de las fotografías fue tomado desde los totales (gran plano general) (las personas se pueden observar en su totalidad y con mucho escenario de fondo). En todas las fotografías, las personas son colocadas en el centro, con menos espacio a su alrededor. Los planos generales (personas retratadas en su totalidad) se encuentran en el $21 \%$ del material fotográfico analizado. Las fotografías en el plano americano conforman el $44 \%$ y en el plano medio, el 32\%. Esta forma de exhibición corresponde a las representaciones usuales de los políticos durante sus alocuciones o en el escenario, luce formal y objetiva, no genera emocionalidad ni una distancia o cercanía especial hacia el escenario.

El nivel de actividad en todas las fotos es mínimo, lo que no sorprende a la luz del encuadre formal. Casi el $67 \%$ de las fotografías con menor o moderada actividad corresponde a los encuadres de negociación, confrontación, legitimidad y éxito. En los momentos y espacios escenificados se desarrolla poca actividad, predominan anuncios, alocuciones y encuentros formales. En casi el $24 \%$ de las fotografías estáticas se observa a los negociadores y políticos individuales haciendo una pose. Solo en el casi $9 \%$ de las fotografías se muestran 
movimientos más rápidos, generalmente durante incursiones militares o demostraciones. Es interesante observar que la creciente actividad va acompañada de una alteración de las negociaciones de paz.

La postura corporal de las personas fotografiadas subraya la representación suministrada por los encuadres. En las imágenes de los anuncios de prensa o de los apretones de mano se muestran las personas de pie, al igual que en los operativos militares (62\% de las fotografías), no obstante, solo el 19\% de las fotografías se encuentra en la mesa y durante las reuniones y rondas de negociación. Ya aquí se puede interpretar un énfasis en la situación formal de la alocución. Los fotógrafos mostraron un menor interés en el trabajo durante las reuniones o las comisiones.

Los medios estilísticos sirven para la desdramatización de la guerra, es decir, del proceso de paz. En lugar de una situación específica se normaliza el proceso apoyando esta impresión mediante el encuadre visual a través de las fotografías. Todas fotografías están más bien distanciadas. Casi no se utilizan medios fotográficos para moralizar o construir una relación emocional con los actores. En el discurso no se presentan encuadres personificadores o visuales sobre situaciones detrás del escenario. El encuadre es objetivo y de ninguna manera creativo o recreativo. Los motivos se repiten frecuentemente. Casi no se usa el "implicit visual propositioning" (Abraham y Appiah, 2006, p. 185).

\section{Conclusiones}

La primera hipótesis pudo ser comprobada ampliamente. En El Tiempo efectivamente se publicaron artículos en 40 de los 50 eventos preseleccionados. El proceso de paz que se prolongó por más de cuatro años intensificó la publicación de artículos en el 2015 y el 2016. Las llamadas alteraciones al desarrollo positivo ocurren especialmente debido a las acciones militares de las FARC. Ni siquiera el rechazo al tratado de paz durante el referendo produjo una cesura ya que se hizo directamente la transición al funcionamiento normal del diálogo político. El encuadre visual del proceso sigue una puesta en escena política estandarizada donde se repiten las imágenes del apretón de manos y del discurso político (Grittmann, 2007). En el encuadre de éxito se presentan tanto los acuerdos de temas individuales de negociación como el cierre y la firma de las negociaciones, el cual además se encuentra cargado especialmente con símbolos religiosos. En línea con esa oferta de interpretación, las FARC son devueltas nuevamente a la normalidad democrática a manera de hijo pródigo y lucen purificadas.

El Tiempo sigue en sentido amplio el llamamiento de Santos en cuanto a "des-escalar" gramaticalmente la identificación del antagonista político. La transformación y humanización de las FARC de actor armado e ilegal a políticamente legal queda completamente plasmada en el encuadre visual. En ninguna parte aparecen las FARC en uniforme. Las fotografías tampoco provocan asociaciones con el narcotráfico, combates militares o terrorismo, como solía suceder en el pasado. Salvo algunas excepciones, se captan imágenes de los representantes de las FARC en el encuadre de crisis desde una perspectiva neutral, y con expresiones y gestos positivos. En lugar de conflictos se habla más bien de acuerdos y tratados en sentido positivo. Podemos descartar la suposición de Serrano (2015, p. 65) "that the way in which journalists have been reporting news about the armed conflict could affect the way they cover the peace talks". La segunda hipótesis queda igualmente confirmada. No obstante, es interesante observar el encuadre mediante la constelación multimodal puesto que a través de los elementos de texto se generan particularmente patrones de identificación que le adjudican la responsabilidad de los problemas a las FARC. Las FARC deben redimirse, disculparse y cumplir con las condiciones del Gobierno. Con ello el Gobierno se destaca a su vez como amo de la situación que fija la marcha de las negociaciones.

Por consiguiente, El Tiempo abre un mayor espacio a los actores del Gobierno, como se espera en la tercera hipótesis, ofreciendo encuadres visuales que apoyan las decisiones del Gobierno y clasifican como competentes a los actores estatales. No obstante, no se esperaba la fuerte presencia y la atribución 
completamente positiva de las fuerzas armadas estatales como garantes del tratado de paz. Para el lector no queda visible en ninguna parte del encuadre que durante gran parte de las negociaciones solo se presentó un cese al fuego unilateral por parte de las FARC y que las incursiones militares continuaron en las regiones dominadas por las FARC. Tampoco se abordaron los innumerables crimines de lesa humanidad por parte de los militares y paramilitares, que habrían podido incluirse al menos bajo el punto de la negociación de las víctimas y la Comisión de la Verdad. Por el contrario, las FARC son vinculadas con las víctimas del conflicto y figuran como principales responsables. Los militares son representados en un papel activo y como actores razonables. A través de los encuadres visuales, se puede afirmar que El Tiempo representa una posición constitutiva y leal al presidente que rara vez se presta como interlocutor de las voces de la oposición o de la sociedad civil, reduciendo la complejidad del conflicto y de las negociaciones a la puesta en escena política desde el punto de vista de la presidencia.

La segunda cuestión del trabajo se enfocó, junto con los componentes de contenido, en una discusión metódica sobre el valor de la teoría del framing para el análisis de conflictos políticos. En nuestra opinión, el planteamiento se presta también para identificar los encuadres visuales de los discursos políticos a nivel de proceso. A fin de realizar una identificación constructiva de encuadres parece razonable registrar no solo los elementos visuales con ayuda del contexto discursivo sino también tomar en serio su multimodalidad. Si se toma en consideración que los lectores leen por encima la mayoría de los artículos registrando solo superficialmente los contenidos, consideramos que los análisis resultantes de la combinación de titular del artículo, imagen y pie de foto son de vital importancia para efectos cognitivos de las imágenes fotográficas en el proceso de percepción. La identificación de encuadres visuales temático-específicos a partir del material mediante una tipología de imágenes y el resumen, y la agrupación de los enunciados principales según una reducción por pasos ha demostrado ser un procedimiento válido. La interacción de textos e imágenes nos ha mostrado que las imágenes con motivos parecidos deben ser clasificadas según la contextualización verbal del artículo en concreto. De esta manera se pudieron descifrar con claridad los significados polisémicos de las imágenes. Consideramos que las variables analíticas de contenido a nivel iconográfico y de estilo formal adecuadas para complementar la descripción discursiva y los rasgos visuales de los encuadres visuales son más oportunas que concluir en encuadres visuales, como lo sugieren algunos autores (Muñiz, Igartua y Otero, 2006; Rodriguez y Dimitrova, 2011; López del Ramo y Humanes, 2016). Llama la atención que nuestros encuadres se han orientado fuertemente hacia los actores retratados (fuerzas militares, Gobierno, delegación del Gobierno y de las FARC en conjunto, FARC). Existen indicios sobre la existencia de similitudes en los encuadres textuales, los cuales se constituyen definitoriamente mediante el "consistente horizonte de sentido de un actor" (Matthes, 2007, p. 139) y la problematización de un contenido a través de un actor. La interacción de texto e imagen permite concluir sobre tales horizontes de sentido, de manera que se pueden elaborar los elementos clásicos del encuadre resultantes de la agrupación de imágenes con el mismo mensaje central.

En resumidas cuentas, el recurso de encuadre visual ofrece una metodología interesante para obtener una visión general de las ideas principales y las posiciones dominantes en un discurso determinado. A pesar de que en la mayoría de los estudios se aplica a temas de conflicto, guerra y catástrofes, el framing visual se presta para temas políticos de cualquier índole debido a su naturaleza antagónica. De igual modo, hace comprensible la parcialidad de los medios de comunicación a favor de la ideología política de ciertos actores y las coaliciones político-mediáticas para la construcción de la hegemonía. No obstante, este artículo se limita al análisis de encuadres visuales en el material mediático sin tener en cuenta todo el proceso del framing, a saber, los modos de producción y aspectos de la recepción de la imagen (Matthes, 2007, pp. 128-130). Un estudio con mayor profundidad debería incluir los diferentes niveles del framing para comprender las repercusiones de las selecciones mediáticas sobre la percepción e interpretación de los acontecimientos políticos de lado de los lectores.

Así mismo, hay que resaltar que el análisis de encuadres también trae consigo dificultades desde una perspectiva lingüística y de análisis de discurso. Entonces, cabe preguntarse si, por ejemplo, el análisis 
de discurso o la interpretación documental de elementos de imagen y texto hacen frente a encuadres interpretativos más complejos. La canonización de la definición de Entman sobre un encuadre aprisiona especialmente la estructura argumentativa del modo comunicativo multimodal dentro de una estrecha faja. La problematización de un contenido no se constituye en único punto de partida de las argumentaciones dentro del discurso. Una mayor consideración de los trabajos lingüísticos para el análisis argumentativo podría ampliar considerablemente el esquema de análisis, aun cuando tendría que reflexionarse esencialmente sobre la definición de encuadres.

\section{Referencias}

Abraham, L., y Appiah, O. (2006). Framing news stories: the role of visual imagery in priming racial stereotypes. Howard Journal of Communication, 17(3), 183-203.

Bocchi, D. (2013). La política exterior colombiana y el costo de ignorar a las organizaciones no gubernamentales. Papel Politico, 18(1), 261-284.

Cabrera, M. (2008). Guerra de imágenes, imágenes de guerra: cuatro eventos mediáticos de la guerra de Iraq. Oasis, (13), 61-88.

Carragee, K. M., y Roefs, W. (2004). The neglect of power in recent framing research. Journal of Communication, 54(2), 214-233.

Coleman, R., y Banning, S. (2006). Network TV news' affective framing of the presidential candidates: evidence for a second-level agenda-setting effect through visual framing. Journalism \& Mass Communication Quarterly, 83(2), 313-328.

Cottle, S., y Rai, M. (2006). Between display and deliberation: analyzing TV news as communicative architecture. Media, Culture \& Society, 28(2), 163-189.

Dahinden, U. (2006). Framing. Eine integrative Theorie der Massenkommunikation. Konstanz: UVK.

De Vreese, C. H. (2005). News framing: theory and typology. Information Design Journal + Document Design, 13(1), 51-62.

Dießelmann, A.-L., y Hetzer, A. (2015). La representación del gobierno Santos y su repercusión en el discurso mediático-político en Europa y Colombia. Análisis Político, 28(84), 3-22.

Dießelmann, A.-L., y Hetzer, A. (2018). La inferioridad del Otro. Estrategias de deslegitimación de la política latinoamericana en el discurso mediático alemán. Chasqui. Revista Latinoamericana de Comunicación, 139, 75-94.

Donati, P. R. (2001). Die Rahmenanalyse politischer Diskurse. En R. Keller (ed.), Handbuch sozialwissenschaftliche Diskursanalyse. Bd. 1: Theorien und Methoden (pp. 145-175). Opladen: Leske + Budrich.

Duarte García, J. (2012). La Unión Europea dentro del "giro" de la política exterior colombiana. Papel Político, 17(2), 679-706.

Dubois, P. (2008). El acto fotográfico y otros ensayos. Buenos Aires: La Marca.

Entman, R. M. (1991). Framing U. S. coverage of international news: contrasts in narratives of the kal and iran air incidents. Journal of Communication, 41(4), 6-27.

Entman, R. M. (1993). Framing: toward clarification of a fractured paradigm. Journal of Communication, 43(4), 51-58.

Entman, R. M. (2004). Projections of power. Framing news, public opinion, and U. S. foreign policy. Chicago/London: University of Chicago Press.

Entman, R. M. (2007). Framing bias: media in the distribution of power. Journal of Communication, 57(2), 163-173.

Entman, R. M. (2010). Media framing biases and political power: explaining slant in news of Campaign 2008. Journalism, 11(4), 389-408.

Entman, R. M., Matthes, J., y Pellicano, L. (2009). Nature, sources, and effects of news framing. En K. Wahl-Jorgensen y T. Hanitzsch (eds.), The handbook of journalism studies (pp. 175-190). New York: Routledge. 
Fahmy, S. (2004). Picturing Afghan women. A content analysis of AP wire photographs during the Taliban regime and after the fall of the Taliban regime. Gazette. The International Journal for Comunication Studies, 66(2), 91-112.

Fontcuberta, J. (1990). Fotografia. Conceptos y procedimientos: una propuesta metodológica. Barcelona: Gustavo Gili.

Galtung, J. (1999). Friedensjournalismus. Niedere und hohe Straße der Konfliktberichterstattung. epdEntwicklungspolitik, 6.

Gamson, W. A. (1992). Talking politics. Cambridge: Cambridge University Press.

Gamson, W. A., y Modigliani, A. (1987). The changing culture of affirmative action. En R. G. Braungart y M. Braungart (eds.), Research in political sociology (pp. 137-177). Greenwich/CT: JAI Press.

Gandy, O. H. (2001). Epilogue - Framing at the horizon: a retrospective assessment. En S. D. Reese, O. H. Gandy y A. E. Grant (eds.), Framing public life. Perspectives on media and our understanding of the social world (pp. 355-378). Mahwah, NJ: Erlbaum.

García-Marrugo, A. (2013). What's in a name? The representation of illegal actors in the internal conflict in the Colombian press. Discourse \& Society, 24(4), 421-445.

Geise, S., Lobinger, K., y Brantner, C. (2013). Fractured Paradigm? Theorien, Konzepte und Methoden der visuellen Framingforschung: Ergebnisse einer systematischen Literaturschau. En S. Geise y K. Lobinger (eds.), Visual Framing. Perspektiven und Herausforderungen der Visuellen Kommunikationsforschung (pp. 42-77). Köln: Von Halem.

Geise, S., y Baden, C. (2013). Bilder Rahmen. Ein integratives Modell (multi-) modaler Informationsverarbeitung im Framing-Prozess. En S. Geise y K. Lobinger (eds.), Visual Framing. Perspektiven und Herausforderungen der Visuellen Kommunikationsforschung (pp. 143-175). Köln: Von Halem.

Geise, S., y Baden, C. (2015). Putting the image back into the frame: modeling the linkage between visual communication and frame-processing theory. Communication Theory, 25, 46-69.

Grittmann, E. (2007). Das politische Bild. Köln: Von Halem.

Grittmann, E. (2013). Visual Frames - Framing Visuals. Zum Zusammenhang von Diskurs, Frame und Bild in den Medien am Beispiel des Klimawandeldiskurses. En S. Geise y K. Lobinger (eds.), Visual Framing. Perspektiven und Herausforderungen der Visuellen Kommunikationsforschung (pp. 95-116). Köln: Von Halem.

Grittmann, E., y Ammann, I. (2011). Quantitative Bildtypenanalyse. En T. Petersen y C. Schwender (eds.), Die Entschlüsselung der Bilder. Methoden zur Erforschung visueller Kommunikation. Ein Handbuch (pp. 163-179). Köln: Von Halem.

Herbers, M. R., y Volpers, A.-M. (2013). Visuelles Framing - Anforderungen an die empirische Forschung und methodologische Konsequenzen. En S. Geise y K. Lobinger (eds.), Visual Framing. Perspektiven und Herausforderungen der Visuellen Kommunikationsforschung (pp. 77-94). Köln: Von Halem.

Lobinger, K., y Geise, S. (2013). "Does the frame remain the same?”. Visual Framing und Multimodalität als theoretische und methodische Herausforderung der Visuellen Kommunikationsforschung. En S. Geise y K. Lobinger (eds.), Visual Framing. Perspektiven und Herausforderungen der Visuellen Kommunikationsforschung (pp. 332-357). Köln: Von Halem.

López de la Roche, F. (2015). Lenguaje, medios de comunicación y proceso de paz. Razón Pública. Recuperado de http://www.razonpublica.com/index.php/politica-y-gobierno-temas-27/8674lenguaje,-medios-de-comunicaci\%C3\%B3n-y-proceso-de-paz.html

López del Ramo, J., y Humanes, M. L. (2016). Análisis de contenido de la representación fotográfica de la crisis de los refugiados sirios y su incidencia en el framing visual. Scire, 22(2), 87-97.

Matthes, J. (2007). Framing-Effekte. Zum Einfluss der Politikberichterstattung auf die Einstellungen der Rezipienten. München: Fischer.

Mayring, P. (2008). Qualitative Inhaltsanalyse. En U. Flick, E. von Kardorff e I. Steinke (eds.), Qualitative Forschung. Ein Handbuch (6. ed.) (pp. 468-475). Reinbek bei Hamburg: Rowohlt-Taschenbuch-Verlag. 
Mellese, M. A., y Müller, M. G. (2012). Mapping text-visual frames of Sub-Saharan Africa in the news: a comparison of online news reports from Al Jazeera and British Broadcasting Corporation websites. Communication, Culture \& Critique, 5(2), 191-229.

Messarias, P., y Abraham, L. (2001). The role of images in framing news stories. En S. D. Reese, O. H. Gandy Jr. y A. E. Grant (eds.), Framing public life. Perspectives on media and our understanding of the social world (pp. 215-226). London: Routledge.

Müller, M. G. (2013). “You cannot unsee a picture!”. Der Visual-Framing-Ansatz in Theorie und Empirie. En S. Geise y K. Lobinger (eds.),Visual Framing. Perspektiven und Herausforderungen der Visuellen Kommunikationsforschung (pp. 19-41). Köln: Von Halem.

Müller, M. G., y Geise, S. (2015). Grundlagen der visuellen Kommunikation (2. ed.). Konstanz: UVK.

Muñiz, C., Igartua, J. J., y Otero, J. A. (2006). Imágenes de la inmigración a través de la fotografía de prensa. Un análisis de contenido. Comunicación y Sociedad, 19(1), 103-128.

Olave Árias, G. (2011). Los marcos del conflicto: aproximación al conflicto armado colombiano desde el concepto de marco. Discurso \& Sociedad, 5(3), 514-546.

Olave Árias, G. (2013). Anuncios de paz en Colombia: una interpretación visual desde el método documental de Karl Mannheim. Revista Colombiana de Sociología, 36(2), 115-139.

Ortega Olivares, M. (2009). Metodología de la sociología visual y su correlato etnológico. Nueva Época, 22(59), 165-184.

Rein, M., y Schon, D. (1991). Frame-reflective policy discourse. En P. Wagner, C. Hirschon Weiss, B. Wittrock y H. Wollman (eds.), Social sciences and modern states. National experiences and theoretical crossroads (pp. 262-289). Cambridge: Cambridge University Press.

Richter, C. (2011). Medienstrategien ägyptischer Islamisten im Kontext von Demokratisierung. Berlin: Frank \& Timme.

Ritchin, F. (2008). After photography. London/New York: W.W. Norton \& Company.

Ritchin, F. (2013). Bending the frame. Photojournalism, documentary and citizen. New York: Aperture.

Rodriguez, L., y Dimitrova, D. V. (2011). The levels of visual framing. Journal of Visual Literacy, 30(1), 48-65.

Scheufele, B. (2003). Frames - Framing - Framing-Effekte. Theoretische und methodische Grundlegung des FramingAnsatzes sowie empirische Befunde zur Nachrichtenproduktion. Wiesbaden: Westdeutscher Verlag.

Serrano, Y. (2015). The strategic issues of journalistic lexicon when reporting on victims of the Colombia armed conflict. Journal of Latin American Communication Research, 5(1), 64-86.

Wanta, W. (1988). The effects of dominant photographs: an agendasetting experiment. Journalism Quarterly, 65(1), 107-111.

Weischenberg, S. (2004). Journalistik. Medienkommunikation: Theorie und Praxis (3a ed.). Wiesbaden: VS.

\section{Notas}

* Artículo de investigación. Esta investigación forma parte del proyecto bilateral "La paz como laboratorio: análisis de las ZVTN y su incidencia en los procesos de normalización de excombatientes de las FARC-EP” entre el Departamento de Ciencias Sociales de la Universidad del Valle, Colombia, y el Departamento de Sociología de la Universidad de Bayreuth, Alemania. El artículo fue traducido del alemán por Marcia I. Lourido Rothenpieler.

[1] Para los diferentes enfoques epistemológicos a lo largo de la historia de la fotografía y la ambigüedad intrínseca de la imagen fotográfica, véanse Fontcuberta (1990), Dubois (2008) y Ritchin (2008, 2013).

[2] En lugar de llamar estos encuadres visuales como lo hicieran Geise, Lobinger y Brantner (2013, p. 65) como "(meta-)frames multimodales", conservamos el término del encuadre visual puesto que no tuvimos en cuenta las noticias periodísticas en su totalidad.

[3] En principio nos ocupamos con ello en el primer nivel de la identificación de encuadres según Rodriguez y Dimitrova (2011, p. 53): "Frames derived from the denotative or representational meanings of that which is depicted are established by the titles, captions, inscriptions, or other textual descriptions that accompany the visual".

[4] El 35\% de los artículos solo contenía una fotografía, el 21\%, dos y el 7\% cuatro, cinco o seis fotografías. El 23\% de los artículos incluyó 7 o más fotografías. 
Licencia Creative Commons CC BY 4.0

Cómo citar este artículo: Dießelmann, A.-L., y Hetzer, A. (2019). Encuadres visuales en las fotografías de prensa del proceso de paz en Colombia. Universitas Humanistica, (88), 1-36. https://doi.org/10.11144/Ja veriana.uh88.evfp 